\title{
Bacillus globisporus subsp. marinus subsp. nov.
}

\author{
H.-J. RÜGER AND G. RICHTER† \\ Institut für Meeresforschung, Am Handelshafen 12, D-2850 Bremerhaven, Federal Republic of Germany
}

Eighteen obligately halophilic psychrophilic Bacillus strains were isolated from Josephine Bank (North East Atlantic) sediment samples collected from different depths. These strains closely resembled those of Bacillus globisporus Larkin and Stokes 1967 (syn.: Bacillus psychrophilus Larkin and Stokes 1967). In contrast to the latter, however, the marine strains had cells which were smaller and which formed terminal or subterminal spores that did not swell the sporangium. The new strains required seawater for growth and did not produce urease. Due to these differences, the marine isolates were placed in a single taxon, Bacillus globisporus subsp. marinus subsp. nov. The type strain of this new subspecies is strain 581 (= ATCC 29841 = DSM 1297).

Aerobic sporeforming bacteria are widely distributed in the marine environment, in seawater as well as marine bottom deposits $(3,6,31)$. However, most of these organisms may be of terrestrial origin. On the other hand, reports of the isolation of obligately halophilic bacilli are rare $(2,23)$, and only one publication (4) giving a complete description of a strictly halophilic bacillus is known to the authors.

From sediment samples collected from different depths of the Josephine Bank (North East Atlantic) and from one station in the Iberian Deep Sea, 18 obligately halophilic psychrophilic Bacillus strains were isolated during two cruises with the RV Meteor (23). The results of a detailed taxonomic study of these halophilic isolates are reported here.

\section{MATERIALS AND METHODS}

Bacterial strains. Isolates were obtained from seawater agar (SWA) pour plates inoculated with 1-ml amounts of serial dilutions of the sediment. The plates were prepared on board the ship immediately after recovery of the samples and were incubated at 13 to $15^{\circ} \mathrm{C}$ for 8 to 15 days (23). Among 460 isolates of heterotrophic bacteria were 18 psychrophilic Bacillus strains which required seawater media for growth. The marine isolates and their sources are listed in Table 1.

Because of their similarity to the marine isolates, the following type strains, obtained from the Deutsche Sammlung von Mikroorganismen (DSM), were also included in this study: Bacillus sphaericus 784 (= American Type Culture Collection [ATCC] $14577=$ DSM 28); B. globisporus 785 (= ATCC $23301=$ DSM $4=$ Larkin and Stokes W $25=$ NRS 1533); B. psychrophilus 786 (= ATCC $23304=$ DSM 3 = Larkin and Stokes $\mathrm{W} 16 \mathrm{~A}=$ NRS 1530).

Methods. (i) General. Unless stated otherwise, all tests were carried out in seawater media at 18 to $20^{\circ} \mathrm{C}$.

† Present address: MILES-KALI-CHEMIE, D-3000 Hannover, Federal Republic of Germany.
The basal media were as follows. Seawater agar (SWA), according to ZoBell: peptone (Difco 0118), 5 g; yeast extract (Difco 0127), 1 g; $\mathrm{FePO}_{4} \cdot 4 \mathrm{H}_{2} \mathrm{O}, 0.01 \mathrm{~g}$; agar (Difco 0140), $15 \mathrm{~g}$; aged seawater, $750 \mathrm{ml}$; and distilled water, $250 \mathrm{ml}$ ( $\mathrm{pH}$ 7.6). Seawater broth (SWB) contained the components of SWA except for agar. Freshwater broth (FWB): peptone, 5 g; yeast extract, $1 \mathrm{~g} ; \mathrm{FePO}_{4} \cdot 4 \mathrm{H}_{2} \mathrm{O}, 0.01 ; \mathrm{NaCl}, 5 \mathrm{~g}$; and distilled water, $1,000 \mathrm{ml}$ (pH 7.6).

(ii) Colonial morphology. The shape and diameter of the colonies were determined from SWA streak plates incubated for 7 days at $20^{\circ} \mathrm{C}$.

(iii) Growth in liquid medium. Growth in SWB was determined after 4 days at $20^{\circ} \mathrm{C}$.

(iv) Morphology of vegetative cells. The size and shape of the vegetative cells were determined by means of phase-contrast microscopy as well as from Gram-stained preparations of 24 -h-old SWB cultures.

The Gram stain was performed according to Hucker's modification (28). However, concentrated iodine solution was used as mordant, and iodized alcohol was employed as decolorizing agent according to Finstein (10). According to Magee et al. (18), available iodine influences the Gram reaction of bacteria.

Motility was determined microscopically with 12 to 24-h-old cultures in SWB; Leifson's method (16) was used for flagellum staining.

(v) Spore formation. Sporulation and spore size were determined in SWA cultures after 4 and 12 weeks under a phase-contrast microscope. In the case of negative results, the following sporulation media were employed: SWA + $15.38 \mathrm{mg}$ of $\mathrm{MnSO}_{4} \cdot \mathrm{H}_{2} \mathrm{O}$; $\mathrm{SWA}+$ $15.38 \mathrm{mg}$ of $\mathrm{MnSO}_{4} \cdot \mathrm{H}_{2} \mathrm{O}+15.38 \mathrm{mg}$ of $\mathrm{CaCl}_{2} \cdot 2 \mathrm{H}_{2} \mathrm{O}$; and SWA $+50 \mathrm{ml}$ of soil extract. To confirm the formation of spores, a modification of Wirtz's method of spore staining (28) was used (a $0.5 \%$ aqueous solution of safranin was used as a counterstain).

(vi) $\mathrm{NaCl}$ requirement. $\mathrm{NaCl}$ requirements of the strains were investigated in FWB with the addition of different $\mathrm{NaCl}$ concentrations: $0,0.5,1,1.5,2,3,3.5,5$, 7 , and $10 \%$. After incubation for 24 and $72 \mathrm{~h}$, growth in these media was measured turbidimetrically at $650 \mathrm{~nm}$ with a Gilford 250 spectrophotometer.

(vii) Enzymatic activities. Because of the marine 
TABLE 1. Designations and origins of strains used in this study

\begin{tabular}{|c|c|c|c|c|}
\hline Strain no. & Cruise no. of RV Meteor & Station no. & $\begin{array}{c}\text { Depth of seawater } \\
\text { (m) }\end{array}$ & North East Atlantic Region \\
\hline 562 & $19 / 1970$ & 210 & 2307 & \\
\hline 565 & $19 / 1970$ & 210 & 230 & \\
\hline 581 & $19 / 1970$ & 211 & 237 & \\
\hline 590 & $19 / 1970$ & 213 & 216 & \\
\hline 591 & $19 / 1970$ & 213 & 216 & \\
\hline 596 & $19 / 1970$ & 213 & 216 & \\
\hline 602 & $19 / 1970$ & 213 & 216 & \\
\hline 603 & $19 / 1970$ & 213 & 216 & Josephine Bank; \\
\hline 604 & $19 / 1970$ & 213 & 216 & \\
\hline 606 & $19 / 1970$ & 213 & 216 & sediment type: coarse \\
\hline 607 & $19 / 1970$ & 213 & 216 & globigerina ooze \\
\hline 609 & $19 / 1970$ & 213 & 216 & \\
\hline 626 & $19 / 1970$ & 215 & 1,684 & \\
\hline 637 & $19 / 1970$ & 215 & 1,684 & \\
\hline 675 & $19 / 1970$ & 217 & 1,028 & \\
\hline 871 & $23 / 1971$ & 135 & 1,445 & \\
\hline 885 & $23 / 1971$ & 135 & 1,445 & \\
\hline 959 & $23 / 1971$ & 149 & 5,112 & $\begin{array}{l}\text { Iberian Deep Sea; } \\
\text { sediment type: fine } \\
\text { globigerina ooze }\end{array}$ \\
\hline
\end{tabular}

character of the isolates, the commonly used identification methods had to be modified. With the exception of the following, the modified methods have been described earlier (30).

In the arginine dihydrolase test, Medium 2A of Thornley (29) was used, but it was prepared with 750 $\mathrm{ml}$ of seawater and $250 \mathrm{ml}$ of distilled water. This medium and a control medium without arginine were solidified with $0.3 \%$ agar and inoculated as stab cultures to differentiate between growth and precipitates from the seawater. The cultures were overlaid with sterile liquid paraffin and incubated for 28 days at $20^{\circ} \mathrm{C}$.

The lysine and ornithine decarboxylase tests were performed with Moeller's decarboxylase base (Difco 0890 ) in the same way as the arginine dihydrolase test.

For the detection of lipolysis, the method of Seki (26) was used.

The indophenol oxidase (cytochrome oxidase) test was performed according to the method of Ewing and Johnson (8) but with the reagents of Gaby and Hadley (11). The strains were cultivated on SWA for $24 \mathrm{~h}$.

The digestion of alginate was determined by the method of Ahrens (1).

Anaerobic growth in SWB and on SWA was evaluated after 7 days of incubation of cultures with the BBL GasPak system.

(viii) Deoxyribonucleic acid (DNA) base composition. Each of four test tubes containing $3 \mathrm{ml}$ of SWB was inoculated with a loopful of a young culture. After a few hours of incubation, the contents of each tube were transferred to a bottle containing $30 \mathrm{ml}$ of SWB and incubated overnight. From each culture, 30 $\mathrm{ml}$ of broth was then used to inoculate $300 \mathrm{ml}$ of SWB in a 1-liter Erlenmeyer flask, and the flasks were shaken at $75 \mathrm{rpm}$ for $48 \mathrm{~h}$ at $20^{\circ} \mathrm{C}$. The cells were subsequently harvested by centrifugation. This procedure yielded 2 to $3 \mathrm{~g}$ (wet weight) of cells and prevented the formation of spores.

Lysis of cells occurred only after prolonged treatment $\left(2 \mathrm{~h}\right.$ at $37^{\circ} \mathrm{C}$ ) with $30 \mathrm{mg}$ of lysozyme per 2 to 3 $g$ (wet weight) of cells and subsequent incubation with sodium dodecyl sulfate at $65^{\circ} \mathrm{C}$ for 30 to $60 \mathrm{~min}$.

DNA was isolated according to the method of Marmur (19). The melting temperature $\left(T_{m}\right)$ of the DNA was determined by the method of Marmur and Doty (20); a Gilford 250 spectrophotometer equipped with a Gilford thermoprogrammer no. 2527 was used. The temperature increase was adjusted to $0.25^{\circ} \mathrm{C} / \mathrm{min}$. The $T_{m}$ curves, traced by a $\mathrm{W}+\mathrm{W}$ Recorder 1100 , were evaluated by the method proposed by Ferragut and Leclerc (9). The guanine plus cytosine $(G+C)$ content of the DNA was calculated from the $T_{m}$ with the formula given by De Ley (5). DNA from Escherichia coli $\mathrm{K}-12$, which has a $T_{m}$ of $90.6^{\circ} \mathrm{C}$ in SSC buffer (5), was used as a standard.

The DNA base ratio for each strain was calculated from nine test results.

(ix) Cell wall composition. Cultivation of cells for the purpose of determining cell wall composition was the same as described for the DNA base analyses. The cells were harvested by centrifugation and were then washed first in distilled water and subsequently in $96 \%$ ethanol. After washing, the cells were stored at $-20^{\circ} \mathrm{C}$ until use.

Cell wall analyses were performed as described by Richter (22). However, for strains 562, 581, 784, and 786 , the cells were extracted with $0.25 \mathrm{~N}$ instead of 0.3 $\mathrm{N} \mathrm{KOH}$.

\section{RESULTS}

Morphology. The cells of the 18 marine strains studied were gram-positive, straight rods with rounded ends; they occurred singly and in pairs. 


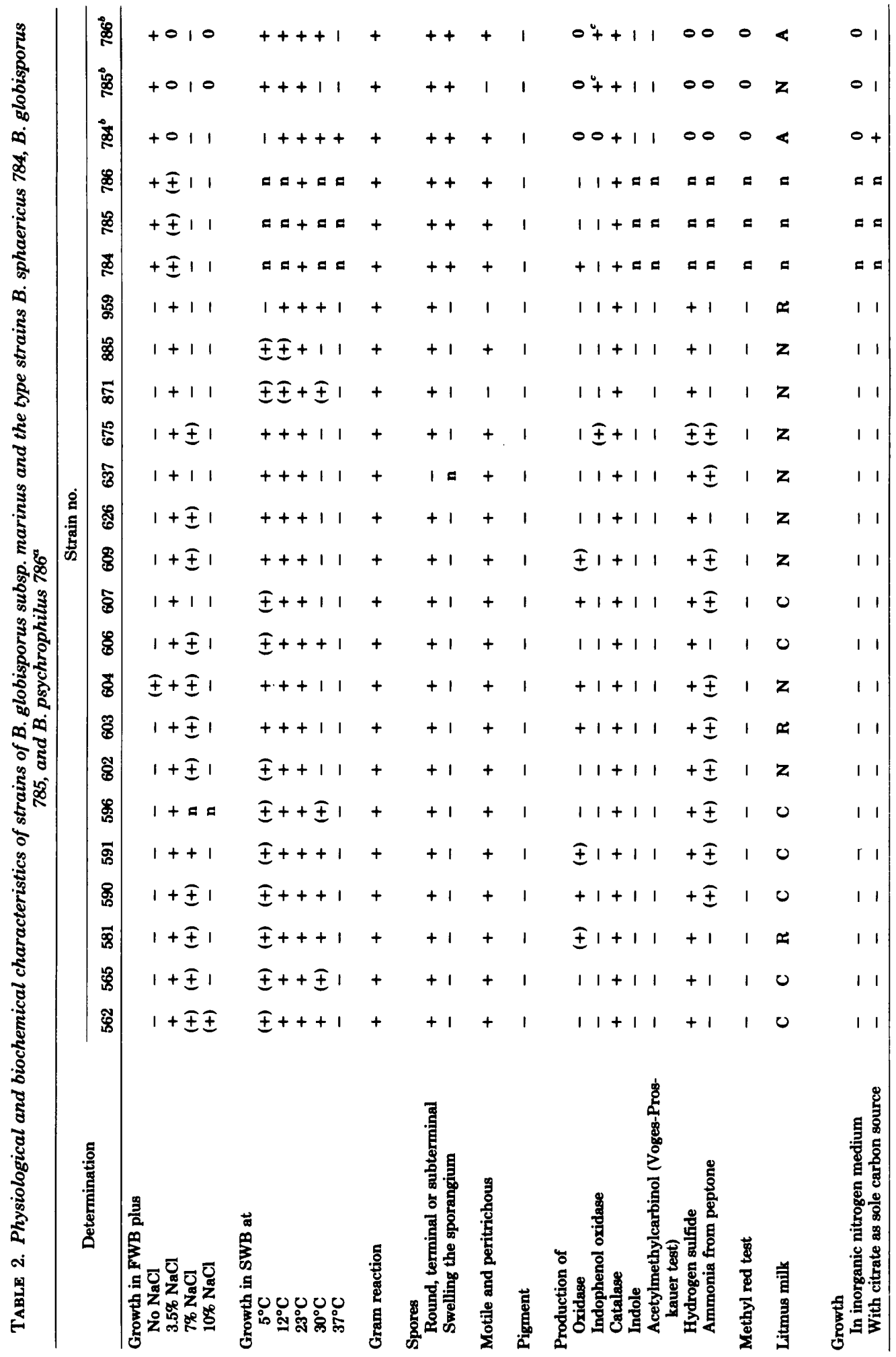




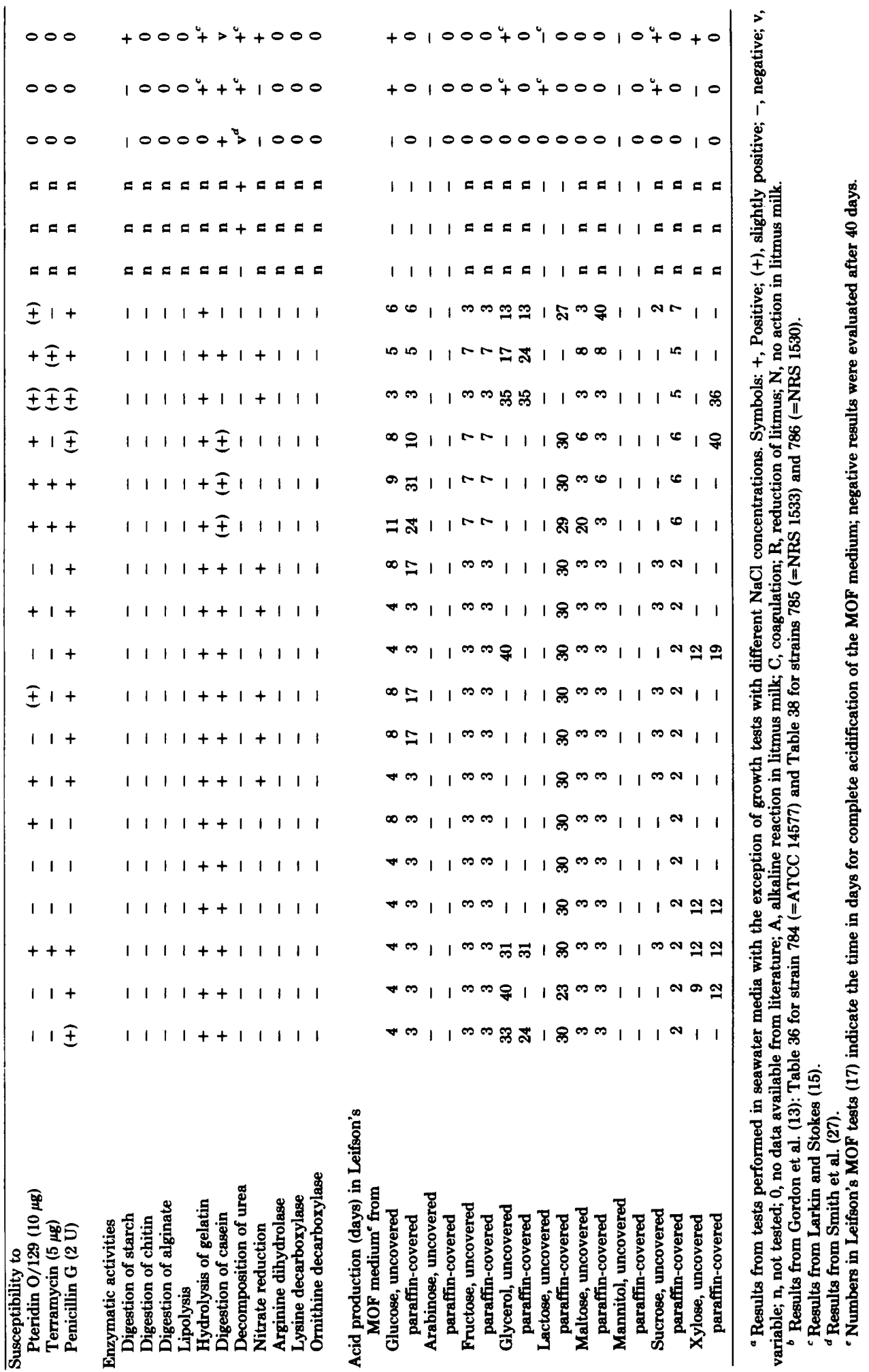


As determined by phase-contrast microscopy, the cells measured 0.7 to 1.2 by 1.5 to $5.0 \mu \mathrm{m}$. Filaments were occasionally observed. Gramstained cells measured 0.5 to 1.0 by 1.25 to 5.0 $\mu \mathrm{m}$.

The cells of Bacillus globisporus strains 785 and 786 were larger than those of the marine strains, measuring 1.0 to 1.4 by 2.0 to $5.0 \mu \mathrm{m}$. Gram-stained cells of these strains measured 0.8 to 1.1 by 1.5 to $4.0 \mu \mathrm{m}$, the dimensions reported by Larkin and Stokes (15).

Sixteen of the marine strains were motile and peritrichous. B. globisporus strain 785 , previously described as nonmotile (reference 13, Table 38), was observed to be actively motile in SWB as well as in FWB.

The cells formed small, round spores, terminal or subterminal, $0: 8$ to $1.0 \mu \mathrm{m}$ in diameter, which did not swell the sporangium. On the other hand, the spores of the strains of B. globisporus and $B$. sphaericus swelled the sporangia. Although four sporulation media were employed, spore formation was not detected with strain 637, which may be a nonsporulating mutant.

Cultural characteristics. After 7 days at $20^{\circ} \mathrm{C}$, SWA colonies of the 18 strains were circular with entire margins, flat to raised, smooth, shiny, translucent, nonpigmented, and 3 to $5 \mathrm{~mm}$ in diameter. Two colony types with different transparencies were observed after culturing freeze-dried or vacuum-dried cells.

After 3 days at $20^{\circ} \mathrm{C}$, a uniform turbidity with a colorless sediment was obtained in SWB. Some strains produced a slight ring.

$\mathrm{NaCl}$ requirements. The strains were obligately halophilic, and only strain 604 grew even slowly in FWB without $\mathrm{NaCl}$.

The $\mathrm{NaCl}$ concentration for optimal growth was between 3.0 and $3.5 \%$ for strains 562,581 , $590,591,596,606,607,609,626,637$, and 675 ; between 1.0 and $3.0 \%$ for strains $565,602,603$, 604 , and 886; and $2 \%$ for strains 871 and 959 . In contrast with the marine isolates, the strains of $B$. globisporus and $B$. sphaericus grew very well at 0 to $1.5 \% \mathrm{NaCl}$, and their growth rates decreased at concentrations exceeding $1.5 \% \mathrm{NaCl}$.

A detailed report of the mineral salt requirements of the marine isolates will be published elsewhere.

Growth temperature. The effects of different growth temperatures on the marine isolates are shown in Table 2. The temperatures for optimal growth were between 12 and $23^{\circ} \mathrm{C}$.

Biochemical characteristics. The results of the biochemical tests, as determined in seawater media, including those of the terrestrial strains 784,785 , and 786 , are given in Table 2 . Additional information on these strains, as given by Gordon et al. (13), is also presented in Table 2. However, some of the tests included in the pres- ently described study were not mentioned by Gordon et al. In these cases, the data of Larkin and Stokes (15) and of Smith et al. (27), derived from all available strains of the species, were used.

The results of the glucose fermentation test and of some of the other tests performed in this study are not in accord with the published data on the strains used. In a supplementary test with the medium of Larkin and Stokes (15), strain 786 fermented glucose after an incubation period of 14 days, whereas strain 785 produced no acid from glucose even after a period of 40 days.

Seven of the 18 strains-581, 602, 603, 604, 607,609 , and 959-produced acid from sucrose during the first 3 days and subsequently reneutralized the medium in the uncovered test tubes. Seven other strains-590, 591, 596, 606, 637, 675, and 871 -showed a very weakly positive reaction only during the first 2 days of incubation; therefore their results are regarded as negative (see Table 2). However, it is also possible that these latter strains are similar to the former, which showed a positive reaction only during the first 3 days.

Anaerobic growth. All strains were strictly aerobic. The results are in accord with those of Gordon et al. (13) for strains 785 and 786, but Larkin and Stokes (15) described both strains as facultatively anaerobic.

DNA base composition. The DNA base ratios of some selected marine strains and for the type strains of $B$. sphaericus, B. globisporus, and $B$. psychrophilus are presented in Table 3.

Bonde (3) reported a DNA base composition of $39.4 \mathrm{~mol} \% \mathrm{G}+\mathrm{C}$ for $B$. sphaericus ATCC 14577, and another strain of this species (ATCC 4525) was reported (20) to have a G+C content of $37 \mathrm{~mol} \%$. The DNA base ratios published by Eiroma et al. (7) for B. globisporus ATCC 23301 $(36.8 \mathrm{~mol} \% \mathrm{G}+\mathrm{C})$ and $B$. psychrophilus ATCC 23304 ( $32.7 \mathrm{~mol} \% \mathrm{G}+\mathrm{C})$ are definitely lower than the results for these strains obtained in this study.

Cell wall composition. Besides the routine biochemical tests, cell wall analyses were per-

TABLE 3. DNA base ratios for selected marine strains and for the type strains $B$. sphaericus 784, $B$. globisporus 785, and B. psychrophilus 786

\begin{tabular}{lc}
\hline \multicolumn{1}{c}{ Strain no. } & $\begin{array}{c}\text { G }+ \text { C content } \\
\text { of DNA } \\
(\mathrm{mol} \%)\end{array}$ \\
\hline 562 & $39.5 \pm 0.9$ \\
581 & $39.3 \pm 0.5$ \\
602 & $36.9 \pm 0.9$ \\
626 & $38.6 \pm 0.8$ \\
784 (B. sphaericus) & $37.6 \pm 1.0$ \\
785 (B. globisporus) & $40.6 \pm 0.6$ \\
786 (B. psychrophilus) & $39.7 \pm 0.3$ \\
\hline
\end{tabular}


formed on the marine strains 562 and 581 and $B$. sphaericus DSM 28. The cell wall of the latter contained lysine and asparagine (25), whereas those of the marine strains contained lysine and glycine (Table 4). The cell walls of $B$. globisporus 785 (= DSM 4) and 786 (= DSM 3) had the same composition (24) as those of the marine strains 562 and 581.

\section{DISCUSSION}

Aerobic, sporeforming bacteria are abundant in the marine environment, and since most of them can grow in freshwater media and at elevated temperatures, they are probably of terrestrial origin. On the other hand, obligately halo- philic bacilli are extremely rare, and only one report of a strictly halophilic bacillus is known to the authors (4). Of 126 sporeforming bacteria isolated from Josephine Bank and Iberian Deep Sea sediments, only 18 were obligately halophilic.

As shown in Table 2, the 18 obligately halophilic strains are closely related to the terrestrial organism $B$. globisporus described by Larkin and Stokes (15) (B. psychrophilus has recently [24] been shown to be a later subjective synonym of $B$. globisporus), but they can be distinguished from this species as follows.

(i) The halophilic strains required $\mathrm{NaCl}$ for growth. Eleven strains showed optimal growth in FWB with 3.0 to $3.5 \% \mathrm{NaCl}$; five strains, with

TABLE 4. Differentiation of B. globisporus from other round-spored species of the genus Bacillus ${ }^{a}$

\begin{tabular}{|c|c|c|c|c|c|c|}
\hline \multirow[b]{2}{*}{ Determination } & \multirow{2}{*}{$\begin{array}{l}\text { B. globisporus } \\
\text { subsp. marinus }\end{array}$} & \multirow{2}{*}{$\begin{array}{l}\text { B. globisporus } \\
\text { subsp. globispo- } \\
\text { rus }^{e}\end{array}$} & \multicolumn{2}{|c|}{ Psychrophilic species } & \multicolumn{2}{|c|}{ Mesophilic species } \\
\hline & & & $\begin{array}{l}\text { B. insoli- } \\
\text { tus }^{c}\end{array}$ & $\begin{array}{l}\text { B. amino- } \\
\text { vorans }\end{array}$ & $\begin{array}{l}\text { B. sphaer- } \\
\text { icus }^{c}\end{array}$ & $\begin{array}{c}\text { B. pantothenti- } \\
\text { cus }^{c}\end{array}$ \\
\hline $\begin{array}{l}\text { Growth in FWB without } \\
\mathrm{NaCl} \\
\text { plus } 10 \% \mathrm{NaCl}\end{array}$ & $\overline{-}$ & $\begin{array}{l}+ \\
-\end{array}$ & $\begin{array}{l}+ \\
-\end{array}$ & $\begin{array}{l}+ \\
-\end{array}$ & + & $\begin{array}{l}+ \\
+\end{array}$ \\
\hline Growth at $5^{\circ} \mathrm{C}$ & + & + & + & + & $\mathbf{v}$ & - \\
\hline $\begin{array}{l}\text { Maximal growth tempera- } \\
\text { ture, }{ }^{\circ} \mathrm{C}\end{array}$ & $25-30$ & $25-30$ & 25 & 35 & $30-45$ & $45-50$ \\
\hline DNA $(\mathrm{mol} \% \mathrm{G}+\mathrm{C})$ & $36.9-39.5^{d}$ & $39.7-40.6^{d}$ & $41.0^{e}$ & $44.3^{f}$ & $37.6^{d}$ & $44.1^{e}-44.8^{\prime}$ \\
\hline $\begin{array}{l}\text { Spores } \\
\text { Round } \\
\text { Oval or cylindrical } \\
\text { Terminal, subterminal } \\
\text { Central } \\
\text { Swelling the sporangium }\end{array}$ & $\begin{array}{l}+ \\
- \\
+ \\
-\end{array}$ & $\begin{array}{l}+ \\
- \\
+ \\
- \\
v\end{array}$ & $\begin{array}{l}\mathbf{v} \\
\mathbf{v} \\
\mathbf{v} \\
\mathbf{v} \\
-\end{array}$ & $\begin{array}{l}+ \\
- \\
- \\
+\end{array}$ & $\begin{array}{l}+ \\
- \\
+ \\
+\end{array}$ & $\begin{array}{l}\mathbf{v} \\
\mathbf{v} \\
+ \\
- \\
+\end{array}$ \\
\hline $\begin{array}{l}\text { Cell walls contain } \\
\text { Asparagine } \\
\text { Glycine } \\
\text { Lysine }\end{array}$ & $\begin{array}{l}- \\
+ \\
+\end{array}$ & $\begin{array}{l}- \\
+ \\
+\end{array}$ & $\begin{array}{l}\mathrm{n} \\
\mathrm{n} \\
\mathrm{n}\end{array}$ & $\begin{array}{l}\mathbf{n} \\
\mathbf{n} \\
\mathbf{n}\end{array}$ & $\begin{array}{l}+ \\
+\end{array}$ & $\begin{array}{l}\mathbf{n} \\
\mathbf{n} \\
\mathbf{n}\end{array}$ \\
\hline $\begin{array}{l}\text { Digestion of } \\
\text { Gelatin } \\
\text { Casein } \\
\text { Urea } \\
\text { Starch }\end{array}$ & $\begin{array}{l}+ \\
v \\
- \\
-\end{array}$ & $\begin{array}{l}+^{2} \\
\mathrm{v} \\
+ \\
\mathrm{v}\end{array}$ & $\begin{array}{l}-8 \\
- \\
- \\
-\end{array}$ & $\begin{array}{l}\mathbf{n} \\
- \\
\mathbf{n} \\
+\end{array}$ & $\begin{array}{l}\mathrm{n} \\
\mathrm{v} \\
\mathrm{v}^{i} \\
-\end{array}$ & $\begin{array}{l}(+)^{h} \\
v \\
-h \\
+\end{array}$ \\
\hline $\begin{array}{l}\text { Acid production from } \\
\text { Glucose } \\
\text { Arabinose } \\
\text { Lactose } \\
\text { Mannitol } \\
\text { Xylose }\end{array}$ & $\begin{array}{l}+ \text { (rapid) } \\
- \\
v \\
- \\
v\end{array}$ & $\begin{array}{l}+(\text { slow }) \\
- \\
v^{g} \\
v \\
v\end{array}$ & $\begin{array}{l}- \\
- \\
-\end{array}$ & $\begin{array}{l}+ \\
- \\
\mathbf{n} \\
- \\
-\end{array}$ & $\begin{array}{l}- \\
- \\
\mathbf{n} \\
-\end{array}$ & $\begin{array}{l}+ \\
+^{h} \\
\mathbf{n} \\
- \\
+^{h}\end{array}$ \\
\hline
\end{tabular}

${ }^{a}$ Symbols: + , Positive; $(+)$, slightly positive; - , negative; $v$, variable (positive and negative strains); n, not tested or no data available from literature.

${ }^{b}$ Summarized results from Table 2.

'Data from Tables 42, 48, and 49 in Gordon et al. (13).

${ }^{d}$ Results from Table 3.

- Data from Eiroma et al. (7).

' Data from Bonde (3).

Data from Larkin and Stokes (15)

${ }^{n}$ Data from Proom and Knight (21).

${ }^{i}$ Data from Smith et al. (27). 
1 to $3 \% \mathrm{NaCl}$; and two strains, with $2 \% \mathrm{NaCl}$. In contrast, $B$. globisporus grew best in 0 to $1.5 \%$ $\mathrm{NaCl}$, and growth rates rapidly decreased in concentrations exceeding $1.5 \% \mathrm{NaCl}$.

(ii) The marine isolates had much smaller cells than the terrestrial $B$. globisporus.

(iii) The marine strains formed small, round spores which did not swell the sporangium; the sporangia of $B$. globisporus 785 and 786 were definitely swollen.

(iv) The marine strains produced no urease within 28 days, whereas $B$. globisporus 785 and 786 were strongly urease positive 2 to $3 \mathrm{~h}$ after incubation.

(v) Larking and Stokes (15) originally described B. psychrophilus and B. globisporus as fermenting glucose. In our hands, however, the type strains of these species gave negative results in the MOF-medium of Leifson (17). In a supplementary test in which the medium of Larkin and Stokes was used, only a weakly positive result was obtained with $B$. psychrophilus 786 after 14 days of incubation; $B$. globisporus 785 remained negative, even after an incubation period of 40 days. Weak or variable results were also reported for these organisms in Bergey's Manual (12). In contrast, the marine isolates completely acidified the fermentation test medium, in most cases within a few days.

Due to these differences, the marine isolates are here regarded as strains of a new subspecies of $B$. globisporus, namely, Bacillus globisporus subsp. marinus subsp. nov., of which strain 581 (=ATCC $29841=$ DSM 1297) is here designated as the type strain. The 10 terrestrial strains originally placed by Larkin and Stokes in $B$. globisporus and B. psychrophilus therefore belong to the automatically created type subspecies, B. globisporus subsp. globisporus. The type strain of the type subspecies is the same as that of the species, i.e. ATCC 23301.

Description of the type strain of B. globisporus subsp. marinus. The cells are grampositive, straight rods with rounded ends and occur singly or in pairs. The average size is 0.9 to 1.2 by 2.0 to $4.0 \mu \mathrm{m}$ by phase-contrast microscopy and 0.5 to 1.0 by 1.5 to $4.0 \mu \mathrm{m}$ in Gramstained preparations. Filaments may be present.

The cells are motile and peritrichous.

Endospores are produced; they are spherical, terminal, or subterminal, 0.8 to $1.0 \mu \mathrm{m}$ in diameter, and do not swell the sporangium.

SWA colonies: Circular with an entire margin, flat, smooth, translucent, nonpigmented, and 3 to $5 \mathrm{~mm}$ in diameter after 7 days at $20^{\circ} \mathrm{C}$.

SWB: Good growth with uniform turbidity and colorless sediment after 4 days at $20^{\circ} \mathrm{C}$.

$\mathrm{NaCl}$ requirement: No growth was observed in FWB without $\mathrm{NaCl}$. The concentration of
$\mathrm{NaCl}$ for optimal growth is between 3.0 and $3.5 \%$. Slight growth occurs with $7 \%$ but not with $10 \% \mathrm{NaCl}$.

Growth temperature: Moderate to good growth occurred at $5^{\circ} \mathrm{C}$. The temperature for optimal growth is between 12 and $23^{\circ} \mathrm{C}$. No growth was observed at $37^{\circ} \mathrm{C}$.

Strictly aerobic.

Catalase was produced. Kovacs oxidase test was slightly positive; when repeated, however, the test gave negative results. Indophenol oxidase (cytochrome oxidase) was not produced.

The methyl red test was negative; acetylmethylcarbinol and indole were not produced.

Hydrogen sulfide was produced within 18 days; ammonia was not produced from peptone.

Nitrate and nitrite were not reduced.

No growth occurred in an inorganic-nitrogen medium, and citrate was not used as a sole carbon source.

Casein was digested and gelatin was liquefied within 3 days. In litmus milk, the litmus was reduced.

Urease, arginine dihydrolase, lysine decarboxylase, and ornithine decarboxylase were not produced.

Susceptible to $10 \mu \mathrm{g}$ of pteridin $0 / 129,5 \mu \mathrm{g}$ of terramycin, and $2 U$ of penicillin $G$.

Starch, chitin, and alginate were not digested, and lipase was not produced.

Acid production in Leifson's MOF medium: Glucose: uncovered, positive within 4 days; paraffin-covered, positive within 3 days. Arabinose: uncovered, negative within 40 days; paraffincovered, negative within 40 days. Fructose: uncovered, positive within 3 days; paraffin-covered, positive within 3 days. Glycerol: uncovered, positive within 31 days; paraffin-covered, positive within 31 days. Lactose: uncovered, negative within 40 days; paraffin-covered, positive within 30 days. Maltose: uncovered, positive within 3 days; paraffin-covered, positive within 3 days. Mannitol: uncovered, negative within 40 days; paraffin-covered, negative within 40 days. Sucrose: uncovered, positive within 3 days, subsequently the test medium was reneutralized; paraffin-covered, positive within 2 days. Xylose: uncovered, positive within 12 days; paraffin-covered, positive within 12 days. Gas was not produced from the carbohydrates tested.

DNA base composition: $39.3 \pm 0.5 \mathrm{~mol} \% \mathrm{G}+\mathrm{C}$ ( $T_{m}$ estimation).

In addition to the type strain, strain 562 was deposited in the American Type Culture Collection and in the Deutsche Sammlung von Mikroorganismen under the numbers 29840 and 1298 , respectively.

B. globisporus cannot easily be differentiated from other round-spored bacilli. In Table 4 are 
listed characters which may be useful for differentiating this species from other round-spored Bacillus species. As shown in Table 4, the other round-spored bacilli differ from $B$. globisporus only with respect to a few criteria, summarized as follows.

$B$. insolitus: This species forms cylindrical as well as round spores located in both terminal and central positions in the sporangia. Gelatin is not liquefied. Casein, urea, and starch are not digested. Acid is not produced from glucose.

B. aminovorans: The spores are central, the maximum temperature for growth is $35^{\circ} \mathrm{C}$, and the $\mathrm{G}+\mathrm{C}$ content of the DNA is $44.3 \mathrm{~mol} \%$.

$B$. sphaericus: The maximum temperature for growth is between 30 and $45^{\circ} \mathrm{C}$. The cell wall contains asparagine but not glycine. All fermentation tests give negative results.

B. pantothenticus: The maximum temperature for growth is between 45 and $50^{\circ} \mathrm{C}$, and the lowest temperature that supports growth is between 15 and $20^{\circ} \mathrm{C}$ (13). Growth occurs at a concentration of $10 \% \mathrm{NaCl}$. Ellipsoidal and spherical spores are present in approximately the same proportion (13). Acid is produced from arabinose in organic basal medium (21). The $\mathrm{G}+\mathrm{C}$ content of the DNA is $44.1 \mathrm{~mol} \%$ according to Eiroma et al. (7) and $44.8 \mathrm{~mol} \%$ according to Bonde (3).

\section{ACKNOWLEDGMENTS}

We thank D. Claus for his advice during the course of this study and T. L. Tan and R. Simonsen for reading the manuscript. The skillful technical assistance of Christa Summa is greatly acknowledged.

We are indebted to the Deutsche Forschungsgemeinschaft for supporting this work.

\section{REPRINT REQUESTS}

Address reprint requests to: Dr. Hans-Jürgen Rüger, Institut für Meeresforschung, Am Handelshafen 12, D-2850 Bremerhaven, Federal Republic of Germany.

\section{LITERATURE CITED}

1. Ahrens, R. 1968. Taxonomische Untersuchungen an sternbildenden Agrobacterium-Arten aus der westlichen Ostsee. Kiel. Meeresforsch. 24:147-173.

2. Boeyé, A., and M. Aerts. 1976. Numerical taxonomy of Bacillus isolates from North Sea sediments. Int. J. Syst. Bacteriol. 26:427-441.

3. Bonde, G. J. 1975. The genus Bacillus. Dan. Med. Bull. 22:41-61.

4. Brisou, J., and F. Denis. 1969. Deux écotypes halophiles stricts de bactéries á Gram positif. C. R. Soc. Biol. 163: 2665-2668

5. De Ley, J. 1970. Reexamination of the association between melting point, buoyant density, and chemical base composition of deoxyribonucleic acid. J. Bacteriol. 101:738-754.

6. Denis, F. 1971. Les Bacillus du milieu marin: étude de 120 souches. C. R. Soc. Biol. 165:2404-2408.

7. Eiroma, M., J. J. Laine, and H. G. Gyllenberg. 1971. DNA base composition in psychrophilic and mesophilic bacilli. Ann. Med. Exp. Biol. Fenn. 49:59-61.

8. Ewing, W. H., and J. G. Johnson. 1960. The differentiation of Aeromonas and C 27 cultures from Entero. bacteriaceae. Int. Bull. Bacteriol. Nomencl. Taxon. 10: 223-230.

9. Ferragut, C., and H. Leclerc. 1976. Etudé comparative des méthodes de détermination du Tm de l'ADN bactérien. Ann. Microbiol. (Inst. Pasteur) 127A:223-235.

10. Finstein, M. S. 1972. Pollution microbiology-a laboratory manual. Marcel Dekker, Inc., New York.

11. Gaby, W. L., and C. Hadley. 1957. Practical laboratory test for the identification of Pseudomonas aeruginosa. J. Bacteriol. 74:356-358.

12. Gibson, T., and R. E. Gordon. 1974. Genus Bacillus Cohn, p. 529-550. In R. E. Buchanan and N. E. Gibbons (ed.), Bergey's manual of determinative bacteriology, 8 th ed. The Williams \& Wilkins Co., Baltimore.

13. Gordon, R. E., W. C. Haynes, and C. H.-N. Pang. 1973 The genus Bacillus. U. S. Department of Agriculture, Handbook no. 427. Washington, D.C

14. Gyllenberg, H. G., and J. J. Laine. 1971. Numerical approach to the taxonomy of psychrophilic bacilli. Ann. Med. Exp. Biol. Fenn. 49:62-66.

15. Larkin, J. M., and J. L. Stokes. 1967. Taxonomy of psychrophilic strains of Bacillus. J. Bacteriol. 94:889895.

16. Leifson, E. 1951. Staining, shape and arrangement of bacterial flagella. J. Bacteriol. 62:377-389.

17. Leifson, E. 1963. Determination of carbohydrate metabolism of marine bacteria. J. Bacteriol. 85:1183-1184.

18. Magee, C. M., G. Rodeheaver, M. T. Edgerton, and R. F. Edlich. 1975. A more reliable Gram staining technic for diagnosis of surgical infections. Am. J. Surg. 130: 341-346.

19. Marmur, J. 1961. A procedure for the isolation of deoxyribonucleic acid from micro-organisms. J. Mol. Biol. 3: 208-218.

20. Marmur, J., and P. Doty. 1962. Determination of the base composition of deoxyribonucleic acid from its thermal denaturation temperature. J. Mol. Biol. 5:109-118.

21. Proom, H., and B. C. J. G. Knight. 1950. Bacillus pantothenticus (n. sp.). J. Gen. Microbiol. 4:539-541.

22. Richter, G. 1977. Routine use of thin-layer chromatography for cell wall analysis of aerobic actinomycetes, including two strains from sediments of the North Sea. Veröff. Inst. Meeresforsch. Bremerhaven 16:125-138.

23. Rüger, H.-J. 1973. Zum Vorkommen aerober sporenbildender Bakterien in nordostatlantischen Tiefseesedimenten. Meteor Forschungsergeb. Reihe D 16:60-64.

24. Rüger, H.-J., and G. Richter. 1979. Bacillus psychrophilus Larkin and Stokes 1967, a later subjective synonym of Bacillus globisporus Larkin and Stokes 1967. Int. J. Syst. Bacteriol. 29:194-195.

25. Schleifer, K. H., and O. Kandler. 1972. Peptidoglycan types of bacterial cell walls and their taxonomic implications. Bacteriol. Rev. 36:407-477.

26. Seki, H. 1967. Ecological studies on the lipolytic activity of microorganisms in the Sea of Aburatsubo Inlet. Rec. Oceanogr. Works Japan 9:75-113.

27. Smith, N. R., R. E. Gordon, and F. E. Clark. 1952. Aerobic sporeforming bacteria. U. S. Department of Agriculture, Agriculture Monograph no. 16, Washington, D.C.

28. Society of American Bacteriologists. 1957. Manual of microbiological methods. McGraw-Hill Book Company, Inc., New York.

29. Thornley, M. J. 1960 . The differentiation of Pseudomonas from other Gram-negative bacteria on the basis of arginine metabolism. J. Appl. Bacteriol. 23:37-52.

30. Weyland, H., H. J. Rüger, and H. Schwarz. 1970. Zur Isolierung und Identifizierung mariner Bakterien. Ein Beitrag zur Standardisierung und Entwicklung adäquater Methoden. Veröff. Inst. Meeresforsch. Bremerhaven 12:269-296.

31. ZoBell, C. F., and H. C. Upham. 1944. A list of marine bacteria including descriptions of sixty new species. Bull. Scripps Inst. Oceanogr. 5:239-292. 